alterations in the activity of the anterior lobe of the pituitary. It is probable that cyclical alterations in adrenal cortical activity still persist in spayed monkeys, and that the consequent hydration and dehydration of the accessory reproductive organs is the factor that is responsible for variations in the responsiveness of these organs to a constant doselevel of œstrone.

Department of Biochemistry, Yale University.

\section{N. H. Long.}

\section{S. ZUCKERMAN.}

Department of Human Anatomy, Oxford.

${ }^{2}$ Zuckerman, S., Nature, 1393 (April 10, 1937).

${ }^{2}$ Anderson, D. H., and Kennedy, H. S., J. Physiol., 78, 247 (1932).

s Stilling, H., Arch. mikr. Anat., 52, 176 (1898).

" Riddle, O., Amer. J. Physiol., 66, 322 (1923).

Thorn, G. W., Garbutt, H. R., Hitcheock, R. A., and Hartman, F. A., Endocr inology, 21, 213 (1937).

- Krohn, P. L., and Zuckerman, S., J. Physiol,, 88, 369 (1937).

'Fisher, R. B., and Zuckerman, S., J. Physiol., 89, 15 P (1937).

8 Kutz, R. L., McKeown, T., and Selye, H., Proc. Soc. Exp. Biol. N.Y., 32, 331 (1934).

Effect of Progesterone on Lactation in the Rat

Drummond-RoBInson and Asdell ${ }^{1}$ showed that ablation of the corpora lutea in the pregnant goat caused milk secretion provided the operation was done after the development of the mammary lobulealveolar system. This suggests that the corpus luteum inhibits lactation prior to parturition, though the

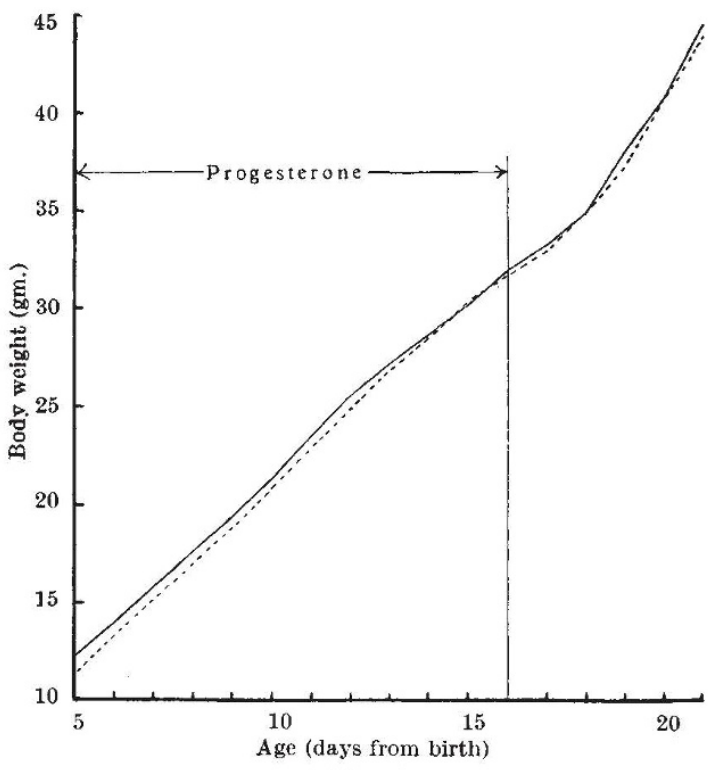

Fig. 1.

AVERAGE GROWTH-RATE OF POOLED LITTERS.

FULL LINE, MOTHERS INJECTED DAILY WITH 1 MGM. PROGESTERONE IN 0.2 ML. ARACHIS OIL. DOTTED LINE, MOTHERS INJECTED DAILY WITH $0.2 \mathrm{MI}$. SFSAME OIL.

work of Anselmino et al..$^{2,3}$ indicates that the inhibitor is different from the hormone which causes proliferation of the uterine endometrium. On the other hand, Frei and Grüter ${ }^{4}$ reported that injections of suspensions of corpus luteum tissue exerted a favourable effect on lactation in the cow. The experiments reported briefly below confirm the contention of
Anselmino et al., since we have found that administration of relatively high doses of pure progesterone to the lactating rat does not inhibit lactation as judged by the rate of growth of sucklings.

Two groups of four lactating rats were used, one experimental and one control. Litters larger than eight were reduced to that number, as is the standard practice in this laboratory. In the case of two of the control rats, the litters numbered seven and six respectively. One litter in each group suffered reduction by the death of a female during the experiment. Each experimental rat was given twelve daily intramuscular injections of $1 \mathrm{mgm}$. crystalline semisynthetic progesterone dissolved in $0.2 \mathrm{ml}$. arachis oil beginning on the fifth day post partum. Total number of young in litters was 17 males and 15 females ; average gain in weight of mothers from parturition to weaning, $21 \mathrm{gm}$. Owing to an error, the controls were given similar injections, not of arachis oil but of sesame oil, but it is extremely unlikely that this would affect the outcome. Total number of young in litters was 14 males and 15 females; average gain in weight of mothers from parturition to weaning, $23 \mathrm{gm}$. We are greatly indebted to Dr. A. N. Macbeth and Messrs. Organon Laboratories Ltd. for the gift of the progesterone used in this work.

The average growth-rates, from the fifth day post partum to weaning, of all the young of each of the two groups of rats are plotted in Fig. 1. It will be seen that there is no difference between the mean growth-rates for the two groups of sucklings, which shows that progesterone, at the relatively high dosage given, neither inhibits established lactation in the rat, nor causes any increase in milk secretion.
National Institute for
S. J. Folley.
S. K. KoN.

Research in Dairying,

University of Reading. April 28.

\footnotetext{
${ }^{1}$ Drummond-Robinson, G., and Asdell, S. A., J. Physiol., 61, 608 (1926).

${ }^{2}$ Anselmino, K. J., Herold, L., Hoffmann, F., and Pencharz, R. I., Zentralbl. Gymäkol., 60, 7 (1936).

Anselmino, K. J., and Hoffmann, F., Zentralbl. Gynäkol., 60, 501 (1936).

'Frei, W., and Grüter, F., Virchows Arch. Path. Anat. Physiol., 275, $638(1930)$
}

\section{Wettability of the Cellulose Walls of the Mesophyll in the Leaf}

THE moisture regain curves (sorption isotherms) of cellulose show a steep rise at high relative humidity, but the water content at saturation (about 18 per cent of the dry weight of raw cotton) is definite both for natural and for regenerated celluloses ${ }^{1}$. To explain why no loosely adhering liquid condenses even when ample time is allowed for dispersal of the heat generated, it is sometimes suggested that the vapour, even under the best controlled experimental con ditions, is never fully saturated. This view is, how ever, difficult to reconcile with the definiteness and reproducibility of the saturation maxima, especially as the regain curves are here so very steep. That these curves have a finite and not an infinite slope at saturation suggests another explanation, namely, that a clean cellulose surface may be incompletely wettable by water.

The unwettability of natural cotton is generally ascribed to the existence of a film of wax or oil covering its outer surface. Masson ${ }^{2}$, who directed attention to the marked rise of temperature which the dried 